\title{
A first outline of the Quaternary landscape evolution of the Kashaf Rud River basin in the drylands of northeastern Iran
}

\author{
Azra Khosravichenar ${ }^{1,2}$, Morteza Fattahi ${ }^{3}$, Alireza Karimi ${ }^{4}$, Hassan Fazeli Nashli ${ }^{5}$, and Hans von Suchodoletz ${ }^{2}$ \\ ${ }^{1}$ Department of Human Evolution, Max Planck Institute for Evolutionary Anthropology, 04103 Leipzig, Germany \\ ${ }^{2}$ Department of Geography, Leipzig University, 04103 Leipzig, Germany \\ ${ }^{3}$ Institute of Geophysics, University of Tehran, Tehran 14155-6466, Iran \\ ${ }^{4}$ Department of Soil Science, Faculty of Agriculture, Ferdowsi University of Mashhad, Mashhad 917794-8974, Iran \\ ${ }^{5}$ Department of Archaeology, University of Tehran, Tehran 14155-6466, Iran
}

Correspondence: Azra Khosravichenar (azra_khosravichenar@eva.mpg.de)

Relevant dates: $\quad$ Received: 28 March 2021 - Revised: 29 April 2021 - Accepted: 7 May 2021 Published: 2 June 2021

How to cite: $\quad$ Khosravichenar, A., Fattahi, M., Karimi, A., Fazeli Nashli, H., and von Suchodoletz, H.: A first outline of the Quaternary landscape evolution of the Kashaf Rud River basin in the drylands of northeastern Iran, E\&G Quaternary Sci. J., 70, 145-150, https://doi.org/10.5194/egqsj-70-145-2021, 2021.

\section{Introduction}

Naturally fragile drylands are among the most sensitive regions to climate change and human activities. More than $80 \%$ of Iran is drylands today, of which large parts represent human settlement centers (Amiri and Eslamian, 2010). Furthermore, the region forms a natural bridge between southwestern, southern, and central Asia for human groups that mainly used three main migration corridors throughout the Pleistocene and Early Holocene (Vahdati Nasab et al., 2013). To better deal with current and future geomorphological and ecological changes in this partly densely settled region and to better understand the geomorphic and paleoenvironmental background of former human dispersal, regional knowledge about such changes on longer centennial to millennial timescales is necessary. Whereas loess-paleosol sequences offer quite well-based information about Late Quaternary paleoenvironmental changes in northern Iran (Kehl, 2009; Lauer et al., 2017), such knowledge is still rather fragmentary for the drylands of eastern and northeastern Iran and is mostly limited to incomplete sediment records of playa lakes or alluvial fans (Walker and Fattahi, 2011; Fattahi and Walker, 2016).
Fluvial archives are very sensitive to climatic and baselevel changes, tectonics, or human activity, making them valuable archives of former geomorphic and paleoenvironmental changes (Macklin and Lewin, 2008; Walker and Fattahi, 2011; Faust and Wolf, 2017; von Suchodoletz et al., 2015 , 2018). Therefore, we recently studied the high mountain Kalshour catchment in northeastern Iran, with a size of some square kilometers, and linked fluvial activity with regional geomorphological and hydrological changes and global solar and temperature fluctuations (Khosravichenar et al., 2020). However, to obtain robust geomorphic and paleoenvironmental information for the larger region, studies of river systems with catchments of several hundreds to thousands of square kilometers are necessary (Faust and Wolf, 2017) but are still lacking for this region. To fill this gap and to offer future research perspectives for this region, we studied the Kashaf Rud River basin in northeastern Iran with a catchment of several thousand square kilometers during a field expedition in 2019 (Fig. 1). This drylands river basin formed part of a Pleistocene to Holocene human migration corridor, linking western and central Asia (Vahdati Nasab et al., 2013; Fig. 1). Our goal was to build up a first fieldbased outline of the Quaternary landscape evolution of the 


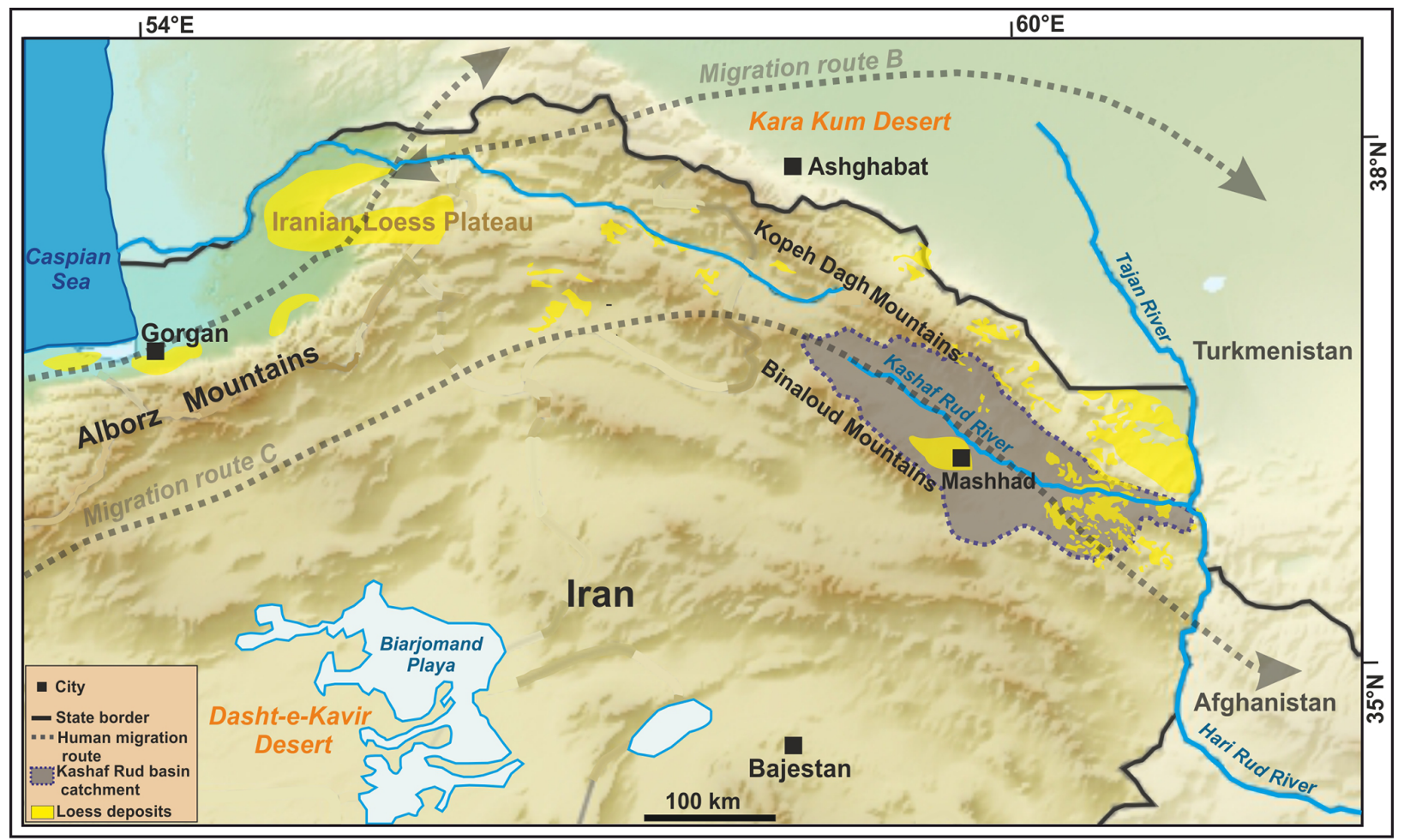

Figure 1. Location of the Kashaf Rud River basin (gray shaded area) in northeastern Iran (digital elevation model sources: GTOPO30, https://earthexplorer.usgs.gov, last access: 1 March 2020; ALOS PALSAR, https://vertex.daac.asf.alaska.edu, last access: 1 March 2020), with loess distribution (geological maps of Khorasan $1: 1000$ and $1: 250$ 000; Lauer et al, 2017) and Pleistocene to Holocene human migration corridors B and C (Vahdati Nasab et al., 2013).

river basin to (i) demonstrate its good suitability as a fluvial archive for Late Quaternary geomorphic and paleoenvironmental changes in the drylands of eastern and northeastern Iran and (ii) offer a first diachronic geomorphic frame for human migrations in a largely unexplored former main human migration corridor (Fig. 1).

\section{Study area and methods}

The ca. $290 \mathrm{~km}$ long northwest-southeast flowing Kashaf Rud River has a catchment of ca. $16800 \mathrm{~km}^{2}$ and a mean annual discharge of ca. $0.64 \mathrm{~m}^{3} \mathrm{~s}^{-1}$ (station Olang-e-Azadi 1992-2007; Regional Water Company of Khorasan Razavi; Fig. 2a). The regional climate is arid to semi-arid today (precipitation ca. $150-550 \mathrm{~mm} \mathrm{a}^{-1}$; https://globalweather.tamu. edu, last access: 1 March 2020). Large parts of the basin are currently covered with patchy loess and loess derivatives (Karimi et al., 2011; Fig. 1), and the basin formed part of Pleistocene to Holocene human migration corridor C of Vahdati Nasab et al. (2013; Fig. 1). Accordingly, Middle and especially Lower Paleolithic stone artifacts were found at several sites (Fig. 2a). In the course of the archeological investigations during the 1970s, the regional landscape context was also partly studied (Ariai and Thibault, 1975; Jamialahmadi et al., 2008).
We investigated a ca. $45 \mathrm{~km}$ long part of the river valley east of the city of Mashhad during a field expedition in 2019 and mapped the main geomorphological and sedimentological features. Here, the riverbed shows altitudes between 900 and $630 \mathrm{~m}$ a.s.1., and precipitation is around $250 \mathrm{~mm} \mathrm{a}^{-1}$ (https://en.climate-data.org, last access: 1 March 2020).

\section{Results}

The studied part of the Kashaf Rud River valley is currently only sparsely vegetated, so its geomorphology and stratigraphical features are well recognizable. The current river flows in a deeply incised gorge-like valley (maximal width ca. $0.8-1.5 \mathrm{~km}$; Fig. $2 \mathrm{~b}$ ). In agreement with the findings of Ariai and Thibault (1975), throughout most of the study area three main morphological terrace levels were observed that are largely naturally outcropped today, offering excellent conditions for geomorphological and sedimentological investigations (Fig. 3).

- T-1. In the lowest and youngest aggradational terrace level (surface ca. 2-4 $\mathrm{m}$ above current river bed; Figs. 2b, 3a, c, g, h), meters-thick, mostly yellowish to ochreous loamy to silty sediments overlie basal gravels and sand. We observed no paleosols within these sedi- 


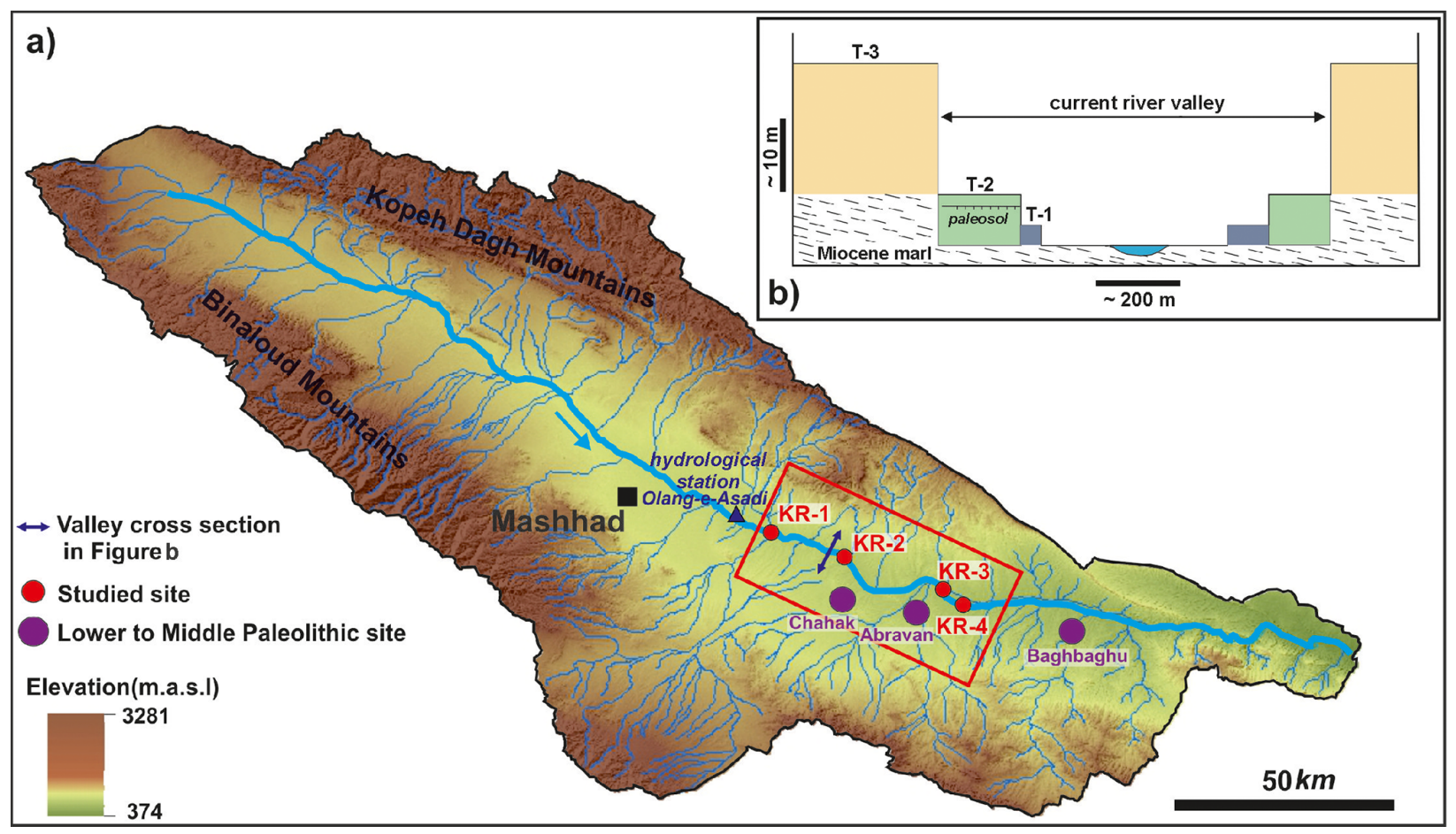

Figure 2. (a) The Kashaf Rud River basin with the study area (red rectangle) and Lower to Middle Paleolithic sites (Ariai and Thibault, 1975; Jamialahmadi et al., 2008). (b) Schematic cross section through the river valley between sites KR-1 and KR-2, with the different terrace levels (for the location, please see panel a).

ments, and the fluvial layers are often easily recognizable (Fig. 3h).

- T-2. In the middle aggradational terrace level (surface ca. 5-7 $\mathrm{m}$ above current river bed; Figs. 2b, 3a-g), meters-thick, mostly yellowish to ochreous loamy to silty sediments overlie basal gravels and sand. At most sites, the fluvial layers are easily recognizable (Fig. 3d). At site KR-1, one weak, slightly reddish and clayey paleosol was found (Fig. 3b). Furthermore, at site KR-3 a brownish clayey paleosol was found (Fig. 3e, f). At the latter site, the river flows in an artificial canal some $100 \mathrm{~m}$ north of the natural river bed (Fig. 3e). Here, the fluvial sediments are covered by up to $>1 \mathrm{~m}$ silty to gravelly sediments originating from the northern slope (Fig. 3e, f).

- T-3. In this highest and oldest aggradational terrace level (surface 40-50 m above current river bed; Figs. 2b, 3c, $\mathrm{e}, \mathrm{g}$ ), decameters-thick sediments, mostly consisting of partly solidified intercalated gravel, sand, and silt layers overlie Miocene marl (Fig. 3g inset). In the upper part, Lower Paleolithic finds were made by Ariai and Thibault (1975). This level was strongly incised when the deeply incised current valley was formed (Fig. 2b), and it marks the surface of a former flat valley with an extension of some kilometers.

\section{Discussion and conclusions}

By combining our field observations with former findings of Ariai and Thibault (1975), we reconstructed the main steps of the Quaternary landscape evolution of the Kashaf Rud River basin as follows:

i. Multi-phased fluvial and lacustrine aggradation of gravelly, sandy and silty material in level T-3, indicating varying hydrological conditions in the Kashaf Rud River basin (Fig. 4a; Ariai and Thibault, 1975). This level must have shown a large extension and a relatively flat topography (Fig. 2b). The higher proportion of gravelly and especially sandy material compared with the following periods indicates a lower importance of silty loess in the landscape during that time. Although the archeological finds of Ariai and Thibault (1975) from the upper part of these sediments were not numerically dated, they are comparable to east African Oldowan tool collections. Therefore, the sediments of terrace level T-3 must have been aggraded during the Early Quaternary.

ii. Fluvial incision of T-3 (Fig. 4b). Given that following level T-2 was aggraded at least from the current river bed, the incision reached down at least to this level. The deep incision shaped the current gorge-like river valley. 

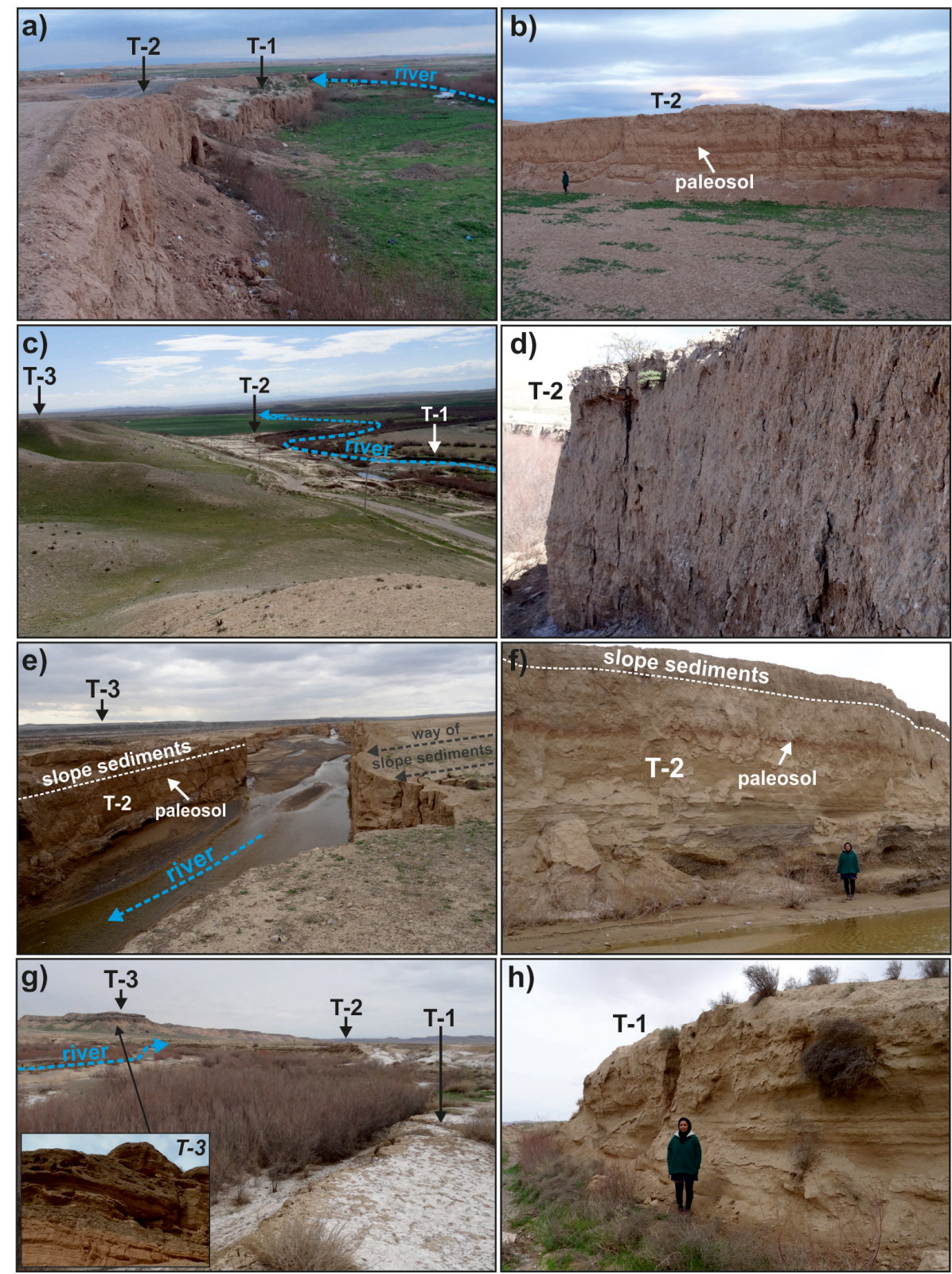

Figure 3. (a, b) Site KR-1 ( $\left.36^{\circ} 14^{\prime} 1.32^{\prime \prime} \mathrm{N}, 59^{\circ} 55^{\prime} 32.04^{\prime \prime} \mathrm{E}\right)$ shows the two mainly silty terrace levels T- 1 and T-2, with at least one weak paleosol in the sediments of T-2 (b). (c, d) Site KR-2 $\left(36^{\circ} 10^{\prime} 34.60^{\prime \prime} \mathrm{N}, 60^{\circ} 4^{\prime} 3.45^{\prime \prime} \mathrm{E}\right)$ shows the two mainly silty terrace levels T-1 and T-2 and terrace level T-3. In level T-2, the fluvial layers are still easily visible (d). (e, f) Site KR-3 $\left(36^{\circ} 10^{\prime} 34.60^{\prime \prime} \mathrm{N}, 60^{\circ} 4^{\prime} 3.45^{\prime \prime} \mathrm{E}\right)$ shows the mainly silty terrace level T-2. Anthropogenic activity diverted the river bed some $100 \mathrm{~m}$ towards the north, where it forms a steep 7-9 $\mathrm{m}$ deep canyon today. Here, the fluvial sediments of T-2 show a well-developed paleosol and are overlain by up to $>1 \mathrm{~m}$ thick gravelly to silty slope sediments. (g, h) Site KR-4 (36 $\left.4^{\prime} 33.35^{\prime \prime} \mathrm{N}, 60^{\circ} 18^{\prime} 39.63^{\prime \prime} \mathrm{E}\right)$ shows the two mainly silty terrace levels T-1 and T-2 and the gravelly to silty level T-3. The fluvial layers are still easily visible in T-1 (h). The inset in panel (g) shows the detail of the sediments in level T-3.

iii. Multi-phased fluvial aggradation of level T-2 (Fig. 4c). The dominance of yellowish to ochreous loamy to silty sediments suggests that they mainly originate from eolian loess that is found in the catchment today (Fig. 1) and shows similar grain sizes and colors (Karimi et al., 2011; Lauer et al., 2017). Loess deposition in northern Iran is known since the Middle Pleistocene (Kehl,
2009). Consequently, we suggest that level T-2 has been deposited since that time. During certain periods, the loess deposits in the river basin must have been strongly reworked by fluvial processes so that they were accumulated as fluvial sediments in the main river valley. Accordingly, Karimi et al. (2011) observed Late Pleistocene periods of strong fluvial reworking of loess de- 
(a) Early Quaternary: Fluvial and lacustrine aggradation (phase I)

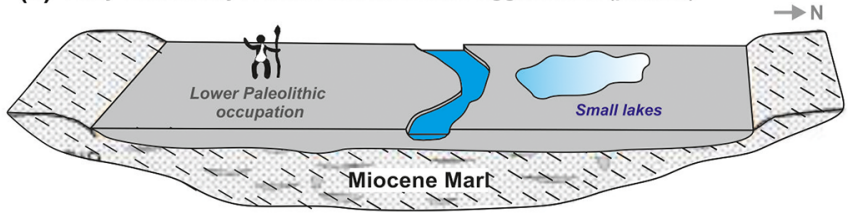

(c) Loess deposition and multi-phased fine-grained silty fluvial aggradation

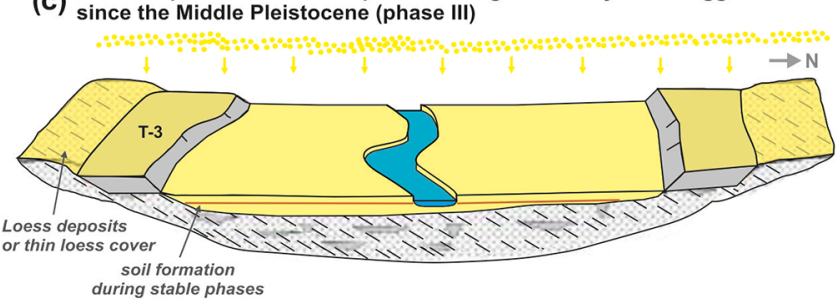
during stable phases

(e) Fine-grained silty fluvial aggradation, and parallel (?) deposition of slope (e) sediments on T-2 (phase V)

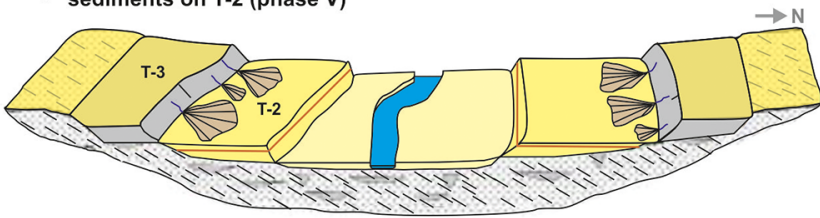

(b) Deep fluvial incision $=$ formation of terrace T-3 (phase II)

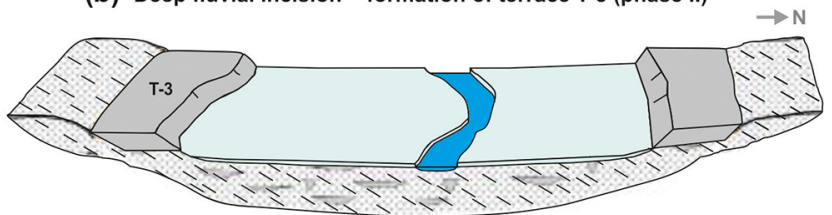

(d) Fluvial incision = formation of terrace T-2 (phase IV)

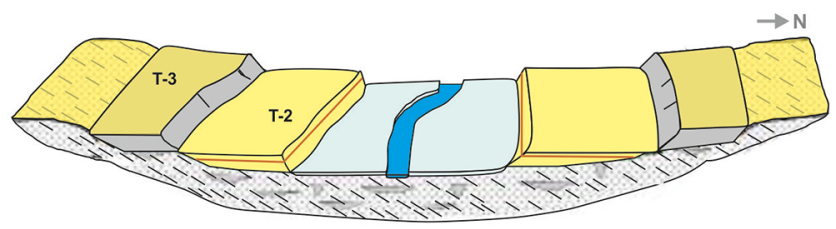

(f) Fluvial incision = formation of terrace T-1 (phase VI)

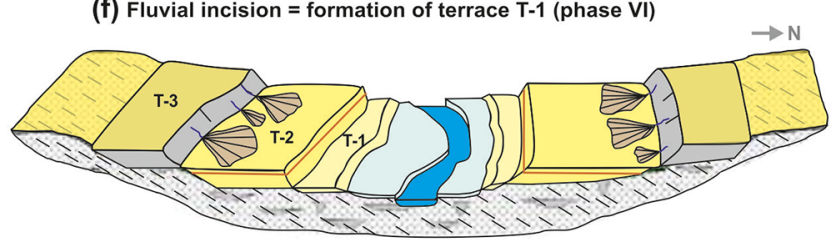

Figure 4. Compiled Quaternary landscape evolution of the Kashaf Rud River basin.

posits in the southwestern part of the Kashaf Rud River basin. At sites KR-1 and KR-3, at least one paleosol was observed in the sediments of level T-2. Therefore, aggradation must have encompassed different phases that were interrupted by at least one period of floodplain stability with soil formation (von Suchodoletz et al., 2018).

iv. Fluvial incision of T-2 (Fig. 4d). Given that following level T-1 was aggraded at least from the current river bed, the incision reached down at least to this level.

v. Fluvial aggradation of level T-1, and coverage of level T-2 by slope deposits (Fig. 4e). Similar to level T2 , in level T-1 mostly yellowish to ochreous loamy to silty loess-borne sediments were aggraded. Furthermore, a strong erosional landscape dynamic is indicated by slope deposits that cover the fluvial sediments of level T-2 at site KR-3 (Fig. 3e, f). Based on our current knowledge, it is not clear whether these two processes were concomitant.

vi. Fluvial incision of level T-1 (Fig. 4f). This incision formed the current river bed.

Terrace levels T-1-T-3 are just morphological forms, so similar levels in different parts of the valley could potentially have been aggraded during different phases (von Suchodoletz et al., 2015; Kolb et al., 2016). Therefore, the Quaternary evolution of the Kashaf Rud River basin must have been much more complex than outlined here. However, already our first field-based findings demonstrate significant geomorphic changes in the basin during the Quaternary. Besides long-term environmental changes, these were possibly also linked with reactions of the river system towards relatively rapid Late Pleistocene and Holocene global climate changes (Macklin and Lewin, 2008). In this context, it remains an open question how far such processes influenced human migrations and activities in human migration corridor C (Fig. 1).

Generally, our field-based results demonstrate the high potential of the well-outcropped sediments in the Kashaf Rud River basin as archives for Late Quaternary geomorphic and linked paleoenvironmental changes in the drylands of eastern and northeastern Iran that must also have influenced human migrations and activities in this region. Specifically, given the high silt content of terrace levels $\mathrm{T}-1$ and $\mathrm{T}-2$, these potentially form complementary sediment archives to formerly studied regional loess-paleosol sequences (Karimi et al., 2011; Lauer et al., 2017); that is, in case of erosion of the loess, corresponding fluvial sediments should have been deposited in the Kashaf Rud River valley. Therefore, more detailed studies of the sediments in the Kashaf Rud river basin, using analytical methods, such as numerical dating and paleoecological analyses, are necessary to contribute to geomorphological, paleoenvironmental, and geoarcheological research, filling a significant knowledge gap in this largely unexplored region.

Data availability. No data sets were used in this article. 
Author contributions. AzK, MF and HvS planned and carried out the fieldwork. AlK contributed to the information on regional loess and HFN on regional archaeology.

Competing interests. The authors declare that they have no conflict of interest.

Acknowledgements. We thank Mohamed Fatemi (Mashhad), Ulrich Göres (Dresden) and Klaus von Suchodoletz (Ballwitz) for their help during fieldwork.

Financial support. The article processing charges for this openaccess publication were covered by the Max Planck Society.

Review statement. This paper was edited by Julia Meister and reviewed by one anonymous referee.

\section{References}

Amiri, M. J. and Eslamian, S. S.: Investigation of climate change in Iran, Journal of Environmental Science and Technology, 3, 208216, 2010.

Ariai, A. and Thibault, C.: Nouvelles precisions a propos de l'outillage paléolithique ancient sur galets du Khorassan (Iran), Paléorient, 3, 101-108, 1975.

Fattahi, M. and Walker, R.: Optical dating of Holocene lake bed sediments of the Nimbluk Plain, Khorasan, Northeast Iran: Implications for the climate change and palaeoenvironment, Journal of the Earth and Space Physics, 41, 1-12, 2016.

Faust, D. and Wolf, D.: Interpreting drivers of change in fluvial archives of the Western Mediterranean - A critical view, Earth-Sci. Rev., 174, 53-83, https://doi.org/10.1016/j.earscirev.2017.09.011, 2017.

Jamialahmadi, M., Vahdati Nasab, H., Fazeli Nashli, H., and Beshkani, A.: Kashafrud revisited: discovery of new Palaeolithic sites in north-eastern Iran. Antiquity 82, project gallery, available at: http://www.antiquity.ac.uk/projgall/nasab317 (last access: 10 February 2021), 2008.

Karimi, A., Frechen, M., Khademi, H., Kehl, M., and Jalalian, A.: Chronostratigraphy of loess deposits in northeast Iran, Quat. Int., 234, 124-132, https://doi.org/10.1016/j.quaint.2009.08.002, 2011.
Kehl, M.: Quaternary climate change in Iran the state of knowledge, Erdkunde, 63, 1-17, https://doi.org/10.3112/erdkunde.2009.01.01, 2009.

Khosravichenar, A., Fattahi, M., Amini, H., and von Suchodoletz, H.: The potential of small mountain river systems for paleoenvironmental reconstructions in drylands - an example from the Binaloud Mountains in northeastern Iran, Geosciences, 10, 448, https://doi.org/10.3390/geosciences10110448, 2020.

Kolb, T., Fuchs, M., and Zöller, L.: Deciphering fluvial landscape evolution by luminescence dating of river terrace formation: A case study from Northern Bavaria, Germany, Suppl., Z. Geomorphol., 60, 29-48, 2016.

Lauer, T., Vlaminck, S., Frechen, M., Rolf, C., Kehl, M., Sharifi, J., Lehndorff, E., and Khormali, F.: The Agh Band loesspaleosol sequence - A terrestrial archive for climatic shifts during the last and penultimate glacial-interglacial cycles in a semiarid region in northern Iran, Quat. Int., 429, 13-30, https://doi.org/10.1016/j.quaint.2016.01.062, 2017.

Macklin, M. G. and Lewin, J.: Alluvial responses to the changing Earth system, Earth Surf. Proc. Land., 33, 1374-1395, https://doi.org/10.1002/esp.1714, 2008.

Vahdati Nasab, H., Clark, G. A., and Torkamandi, S.: Late Pleistocene dispersal corridors across the Iranian Plateau: A case study from Mirak, a Middle Paleolithic site on the northern edge of the Iranian Central desert (Dasht-e Kavir), Quat. Int., 300, 267-281, https://doi.org/10.1016/j.quaint.2012.11.028, 2013.

von Suchodoletz, H., Menz, M., Kühn, P., Sukhishvili, L., and Faust, D.: Fluvial sediments of the Algeti River in southeastern Georgia - An archive of Late Quaternary landscape activity and stability in the Transcaucasian region, Catena, 130, 95-107, https://doi.org/10.1016/j.catena.2014.06.019, 2015.

von Suchodoletz, H., Zielhofer, C., Hoth, S., Umlauft, J., Schneider, B., Zeeden, C., Sukhishvili, L., and Faust, D.: North Atlantic influence on Holocene flooding in the southern Greater Caucasus, Holocene, 28, 254-269, https://doi.org/10.1177/0959683617735584, 2018.

Walker, R. T. and Fattahi, M.: A framework of Holocene and Late Pleistocene environmental change in eastern Iran inferred from the dating of periods of alluvial fan abandonment, river terracing, and lake deposition, Quat. Sci. Rev., 30, 1256-1271, https://doi.org/10.1016/j.quascirev.2011.03.004, 2011. 